\title{
VASCULAR ACCESS
}

\section{Message from the President}

For referencing Sutherland M. Message from the President. Vascular Access 2021; 7(2):3.

Dol https://doi.org/10.33235/va.7.2.3

\section{Hello Vascular Access enthusiasts,}

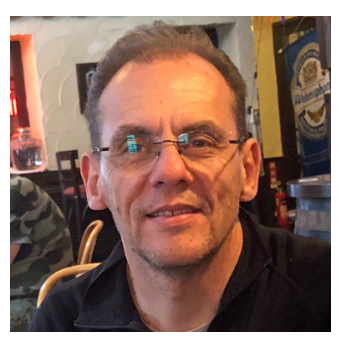

I'll be brief. The dreaded pandemic has overwhelmed my world since I wrote my last President's Message. The past six months has seen my State go from one of near normal life with casual compliancy towards the virus to all hospital services having to bow in submission to COVID and focus only on COVID. The good news is our numbers have peaked and our hospitals are coping. Granted, some better than others, but there is light at the end of the tunnel.

How does this relate to the growth and development of vascular access, which to say is the heart and soul of a peer review publication? This nasty virus has so overwhelmed my personal and professional world that I find I have not had time to smell the roses and I believe I am not alone. All this time, the focus of COVID stopped me realising that my daily clinical load is full of experiences and learning opportunities that I lost time to reflect on.

It's a crime that I don't share those experiences with you, my vascular access colleagues. My message to you is learn from my mistake; no matter how busy you get, no matter how distracted you become, take a moment, reflect, and share your experiences, knowledge and investigative conclusions with us, your vascular access colleagues. Publish in publications such as this one and the AVAS Newsletter and we all will be the richer for it.

Kind regards,

Mark Sutherland RN, ICCert(NSWCN), BHSN

President, AVAS 